\title{
Revisiting the 'Informational City': Space of Flows, Polycentricity and the Geography of Knowledge-Intensive Business Services in the Emerging Global City-Region of Dublin
}

\author{
MARTIN SOKOL*, CHRIS VAN EGERAAT $†$ and BRENDAN WILLIAMS $\ddagger$ \\ *Department of Geography, Queen Mary, University of London, Mile End Road, London E1 4NS, UK. \\ Email:m.sokol@qmul.ac.uk \\ †Department of Geography/NIRSA, John Hume Building, NUI Maynooth, Maynooth, Ireland. \\ Email: chris.vanegeraat@nuim.ie \\ $\ddagger U C D$ School of Geography, Planning and Environmental Policy, University College Dublin, Richview,
}

Dublin 14, Ireland. Email: brendan.williams@ucd.ie

(Received October 2006: in revised form October 2007)

Sokol M., VAn Egeraat C. and Williams B. Revisiting the 'informational city': space of flows, polycentricity and the geography of knowledge-intensive business services in the emerging global city-region of Dublin, Regional Studies. The paper engages with the notion that the new spatial logic, underpinned by information and communication technology (ICT) and the 'space of flows', manifests itself in the form of 'informational cities' described as multinuclear spatial structures or polycentric city-regions in the knowledge-based economy. Focusing on the geography of knowledge-intensive business services (KIBS), the paper argues that there is little evidence of such polycentric pattern emerging within the Greater Dublin Region, Ireland. The exploration of factors underpinning weak decentralization tendencies of KIBS opens for reconsideration the concept of the 'informational city'.

Knowledge-intensive business services (KIBS) Polycentricity City-region Dublin

SOKOl M., VAn EgERAAT C. and Williams B. 重访 “信息城市” : 都柏林新兴的全球城市区域内部流空间、多中心性、 以及知识密集型服务业地理学，区域研究。基于信息交流技术（ICT）以及 “流空间” 的新空间逻辑以 “信息城市” 为其主要表达形式, 这一空间逻辑被描述为知识经济背景下的多核心空间结构或多中心城市区域。围绕知识密集 型产业地理学 (KIBS), 文章认为, 鲜有证据表明这种多中心模式正在大都柏林区域出现。基于知识密集型服务 业逆中心趋势影响要素进行的探讨为重新定义“信息城市” 提供了可能性。

\section{知识密集型服务业 多中心性 城市区域 都柏林}

Sokol M., Van Egeraat C. et Williams B. Revisiter la cité de l'information: espace de flux, polycentricité et géographie des secteurs à haute densité intellectuelle aux entreprises basés sur la connaissance dans la nouvelle ville-région de Dublin, Regional Studies. Cet article s'intéresse au fait que la nouvelle logique spatiale, sous-tendue par les technologies de l'information et de la communication (TIC) et les espaces de flux se manifeste sous la forme de cités de l'information décrites comme des structures spatiales à noyaux multiples ou de villes-régions polycentriques dans l'économie de la connaissance. S'appuyant essentiellement sur la géographie des secteurs à haute densité intellectuelle (KIBS), les auteurs font valoir qu'il y a peu de preuves de l'émergence de tels modèles polycentriques au sein du grand Dublin. L'analyse de facteurs confirmant de faibles tendances à la décentralisation des KIBS invite à reconsidérer le concept de cité de l'information.

Secteurs à haute densité intellectuelle Polycentricité Ville-région Dublin

Sokol M., Van Egeraat C. und Williams B. Neubewertung der 'Informationsstadt': Raum der Ströme, Polyzentrizität und die Geografie von wissensintensiven Geschäftsdiensten in der entstehenden globalen Stadtregion von Dublin, Regional Studies. In diesem Beitrag befassen wir uns mit der Vorstellung, dass sich die neue räumliche Logik dank der Informations- und Kommunikationstechnologie und des 'Raums der Ströme' in Form von 'Informationsstädten' manifestiert, die als multinukleare Raumstrukturen oder polyzentrische Stadtregionen in der wissensbasierten Wirtschaft beschrieben werden. Wir konzentrieren uns auf die Geografie von wissensintensiven Geschäftsdiensten und argumentieren, dass innerhalb der Großregion Dublin nur wenige Anzeichen für das Entstehen solcher polyzentrischer Muster vorliegen. Die Untersuchung von Faktoren, die schwachen 
Dezentralisierungstendenzen von wissensintensiven Geschäftsdiensten zugrundeliegen, führt zu einer Neubewertung des Konzepts der 'Informationsstadt'.

Wissensintensive Geschäftsdienste Polyzentrizität Stadtregion Dublin

Sokol M., Van Egeraat C. y Williams B. Revisión de la 'Ciudad Informativa': espacio de flujos, policentralidad y la geografia de los servicios comerciales con alto nivel de conocimientos en el área emergente y global de la región metropolitana de Dublín, Regional Studies. Este ensayo trata sobre la noción de que la nueva lógica espacial, respaldada por las tecnologías de la información y la comunicación (TIC) y el 'espacio de flujos', se manifiesta en forma de 'ciudades informativas' descritas como estructuras multinucleares espaciales o regiones metropolitanas policéntricas en la economía basada en el conocimiento. Centrándonos en la geografia de servicios comerciales con alto nivel de conocimientos, en este artículo sostenemos que existen pocas evidencias de este modelo policéntrico en la región metropolitana de Dublín. El análisis de los factores detrás de las tendencias débiles de descentralización de los servicios comerciales con alto nivel de conocimientos nos lleva a reconsiderar el concepto de la 'ciudad informativa'.

Servicios comerciales con alto nivel de conocimientos Policentralidad Región metropolitana Dublín

JEL classifications: L80, O18, R12, R30

\section{INTRODUCTION}

The twin processes of globalization and knowledge intensification of the economic processes said to be resulting in the emergence of the 'global knowledgebased economy' have raised serious questions about the future of cities and regions. A commonplace view is that the new global knowledge-based economy will bring about new spatial forms or even an entirely 'new spatial logic' (CASTELLS, 1989) superseding spatial forms, or the existing spatial logic of industrial capitalism. In recent decades this 'new spatial logic' has been subject to an intensifying debate. Interestingly, there has been a strong convergence of views among the leading scholars identifying 'polycentricity' or 'multinuclearity' as a defining feature of the city-region of the 21 st century - in the form of 'multi-core metropolis' (HALL, 1999, pp. 18-19), 'multiclustered agglomerations' (SCOTT et al., 2001, p. 18), 'new geographies of centrality' (SASSEN, 2001, p. 85), or 'multifunctional, multinuclear spatial structures' (CASTELlS, 1989, p. 167). More recently, Hall and PaIN (2006) have used terms such as 'polyopolis', 'polycentric metropolis' or 'polycentric mega-city region' to describe what they call a 'new spatial phenomenon' (p. 14). Importantly, spatial structures that are characterized by some form of polycentricity are also favoured by policy-makers who often see them as a way of ensuring more balanced development at various spatial scales (e.g. EUROPEAN Communities, 1999).

However, there are two key questions that the polycentric debate needs to address: (1) whether a 'multinuclear' or 'polycentric city-region' is indeed emerging as a dominant spatial form of the knowledgebased economy, and if so, (2) whether such a cityregion contributes to balanced spatial development. The challenges in addressing these two questions are significant. One of the key problems is the fact that the concept of polycentricity is itself subject to an important debate that leaves a definition of a 'polycentric city-region' somewhat problematic and inconclusive (e.g. RICHARDSON and JENSEN, 2000; Jensen and Richardson, 2001; Bailey and Turok, 2001; Kloosterman and Musterd, 2001; Kloosterman and Lambregts, 2001; Davoudi, 2003; Turok and Bailey, 2004; Parr, 2004). In the absence of a generally accepted conceptual framework, this paper will refer to definitions proposed most recently by HALL and PAIN (2006) - who view 'polycentric mega-city regions' as emerging through a 'long process of very extended decentralization from large central cities to adjacent smaller ones' (p. 3) or 'outward diffusion from major cities to smaller cities within their spheres of influence' (p. 12). Clearly, definitional issues alone would deserve a detailed discussion or even a full paper (see the other contributions in this issue), but this is not the intention of this paper.

Instead, this paper focuses on the factors impinging upon the fundamental process through which a 'polycentric mega-city region' is supposed to be created, i.e. the process of 'decentralization' or 'outward diffusion'. The paper will do so by engaging with the conceptual approach of the 'space of flows' (CASTELLS, 1989, 2000). There are at least two good reasons for this. First, it has been argued recently that a 'polycentric mega-city region' is in fact 'based on Castells's "space of flows"'(Hall and Pain, 2006, p. 12). The second reason is that CASTELLS (1989) developed a fairly comprehensive theoretical framework that may help to understand the emergence of such a city-region. Indeed, some years ago, CASTELls (1989) predicted the emergence of 'informational cities' in a form of 'multifunctional, multinuclear spatial structures' resulting from the balance of centralizing and decentralizing effects of the 'space of flows' in the 'information age' dominated by information and communication technologies (ICT).

The main aim of the present paper is to examine key aspects of the Castells's theory (summarized in the 
second section) in the light of empirical evidence from the Greater Dublin region. The choice of Dublin can be justified on two grounds. Firstly, Dublin has been strongly exposed to the forces of globalization over the last two decades. The increasing linkages with the global economy have recently led researchers from the Globalization and World Cities Study Group and Network (GaWC) to label Dublin an 'emerging global city' (TAYLOR et al., 2002, p. 100). Secondly, it could be argued that hand-in-hand with its globalization, Dublin experienced unprecedented economic growth, part of which was a significant expansion of internationally traded services (BREATHNACH, 2000; GRIMEs, 2003; Grimes and White, 2005) and knowledge-intensive business services (KIBS). Importantly, CASTELLS (1989) and HALL and PAIN (2006) alike see KIBS as the major driving force behind the emergence of the 'multinuclear' or 'polycentric' spatial structures. With both key ingredients present - high exposure to globalization processes and a strong presence of KIBS - Dublin is a good case for an examination of whether the 'new spatial logic' is taking roots (and, if so, whether more balanced development is emerging as a result).

However, following the examination undertaken in the third section, it will be argued that the geography of KIBS in and around Dublin does not seem to imply that either dramatically new 'spatial logic' or more balanced development is emerging. The subsequent sections of the paper will therefore examine factors that impinge upon the processes of centralization and decentralization in the region in order to establish why centralizing tendencies are dominant and whether there are factors that may encourage decentralization of KIBS in the future. In doing so, the paper will aim to argue that, in addition to the role of ICT (over)emphasized by Castells, a much more complex set of factors shaping the geography of KIBS is in operation, thus highlighting the need to reconceptualize the 'informational city'. The paper will suggest that there is a need for a conceptual approach that would be more sensitive to a number of other crucial factors such as the role of the state (in its various geographical scales), the labour market conditions and locational strategies of KIBS themselves, the importance of which will be highlighted by the evidence presented in the fourth to sixth sections. Furthermore, and importantly, it will be argued that a combined effect of these factors may not necessarily support the emergence of 'polycentric'spatial structures. Finally, the seventh section will summarize the arguments and highlight challenges for policy-making.

\section{'SPACE OF FLOWS' AND THE 'NEW SPATIAL LOGIC'}

The concept of the 'space of flows' is frequently used, but also often misinterpreted. Manuel Castells, the originator of the concept, himself contributed to the confusion by offering alternative definitions and interpretations of the 'space of flows' (cf. CASTELls, 1989, versus CASTELLS, 2000). This paper will use the original conceptual approach developed by CASTELLS (1989) in his seminal work The Informational City: Information Technology, Economic Restructuring and the Urban-Regional Process. In it he provides the clearest expression of what is meant by 'space of flows' while using a conceptualization which is directly relevant to the polycentricity debate (HALL and PAIN, 2006, pp. 3-4). It is worth mentioning that, in his later writings, Castells has shifted his analytical focus and changed vocabulary somewhat. However, his emphasis on ICTs remained intact (CASTELLS, 2000, 2001, 2004) and the continued relevance of The Informational City for his concept of the 'space of flows' has been explicitly acknowledged (CASTELLS, 2000, p. 409, n. 3).

The key arguments of CASTELLS (1989) could be summarized as follows. The starting point of Castells's theorization is a suggestion that prevailing spatial forms are inextricably linked with dominant social organization of societies. In other words, if a new social organization sets in, new spatial form will follow. According to Castells (1989), new social organization is indeed emerging, giving birth to an entirely new 'spatial logic'. It was the advent of ICTs that provided a trigger for transformation towards a new mode of socio-technical organization - 'informational mode of development' (also CASTELLS, 2000). He agues that through this transformation the economy becomes informational, because the production of surplus derives mainly from the generation of knowledge and from the processing of necessary information' (CAstells, 1989, p. 136; also CAstells, 2000, p. 77; 2004, pp. 8-13). He puts forward a hypothesis that this new 'informational mode of development', together with the process of restructuring of capitalism, forms a 'fundamental matrix of institutional and economic organization in our societies' (CASTELLS, 1989, p. 2).

CASTElls (1989) offers a detailed description of this new organizational matrix and the way it impacts on cities and regions. He asserts that one of the key features of this new matrix is the 'large-scale organization', in particular the large private corporation (CASTELLS, 1989, p. 137). While small and medium enterprises may continue to play a dynamic role in the economy, their 'role is auxiliary in relation to processes that depend largely on the commanding heights of the economy' (p. 137) dominated by large corporations. Castells also makes a point that although informational mode of development penetrates all spheres of the economy (including agriculture and manufacturing; p. 167), it is a 'nucleus of information-intensive industries whose organization and spatial logic occupies the top of the functional and economic corporate hierarchy' (p. 144; for a similar argument, see also TAYLOR et al., 2002). Castells's definition of 'information-intensive industries' corresponds 
to KIBS, including banking and finance, insurance, legal service, engineering, accounting, and other business services (CASTELLS, 1989, p. 144). In other words, Castells argues that KIBS play a pivotal role in shaping the new spatial structure (also TAYLOR et al., 2002) and its potentially polycentric form (also HALL and PAIN, 2006).

CAstells (1989) then offers more details on how this new (polycentric) spatial structure will come about. He suggests that, thanks to new information technologies, large office-based information-intensive corporations (read KIBS) are dramatically transforming their organizational and spatial structure, resulting in a 'complex, hierarchical, diversified organizational structure' characterized by a 'variable geometry depending upon time, place, and realm of activity' (p. 168). He argues that in terms of spatial structure these corporations are undergoing a 'two-fold process of simultaneous centralization and decentralization' (p. 151). By centralization he means 'metropolitanization' of service activities (p. 151) or reinforcement of decision-making in corporate cores of major central business districts (CBD; p. 167). By 'decentralization' he understands a spread of service activities over three spatial levels: from inner cities to the suburbs of metropolitan areas; from metropolitan to non-metropolitan areas and small cities; and between regions (p. 152). ${ }^{1}$ $\mathrm{He}$ argues that the process of office centralization or decentralization is differentiated according to the different types of office functions and their place in the hierarchy of the corporation (p. 159), resulting in a 'complex territorial development process' (p. 169). This complex process - where 'neither centralization nor decentralization is dominant' (p. 169; added emphasis)

- impacts on the urban-regional structure and transforms metropolitan areas into 'multifunctional, multinuclear spatial structures' (pp. 156, 167). ${ }^{2}$

Importantly, all various office functions within a corporation (from head office to back offices) regardless of their actual location have to be interrelated and interconnected by the means of 'communication flows' (CAstells, 1989, p. 169) via ICT infrastructure. ${ }^{3}$ Consequently, the 'space of organizations in the informational economy is increasingly a space of flows' (p. 169). Crucial for the understanding of this emerging 'new spatial logic', however, is the recognition that the 'space of flows' and the creation of 'multifunctional, multinuclear spatial structures' is not an undifferentiated process (p. 167). Rather, it follows a 'hierarchical and functional logic' (p. 167). In other words, flows are 'structured' and possess 'directionality' (p. 170) as a result of both hierarchical corporate structure and ICT infrastructure available. It follows, then, that the impact of the 'new spatial form' on balanced development may be problematic (also SCOTT et al., 2001). CASTELLS (1989) fully acknowledged this and indeed predicted the increase of spatial and social inequality (p. 346).

In drawing these conclusions, CASTELls (1989) relied on the data from the USA which he regarded as 'the most advanced society [...] in the production and use of new information technologies' (p. 4). However, he contends that by identifying socio-spatial effects of macro-processes that are fundamental to all advanced capitalist societies, his theory is 'intended to aid understanding of the techno-economic transformation of the urban-regional process in a broad range of social contexts' (p. 5). This paper will explore the factors behind this urban-regional process in the context of Dublin, an emerging global city-region.

\section{DUBLIN: TOWARDS AN INFORMATIONAL CITY?}

Dublin - with its high exposure to globalization and large presence of knowledge-intensive service firms is a good case to study the effects of the Castells's 'informational' mode of development. In terms of size, Dublin would also qualify as one of the "large metropolitan areas' analysed by CASTELLS (1989, p. 145, table 3.6), although arguably at the lower end of the scale - the population of the Greater Dublin region in 2001 was 1.64 million, of which the Dublin metropolitan area accounted for 1.12 million inhabitants.

The key aim of the present investigation is to establish whether the forces of simultaneous centralization and decentralization are present in and around Dublin resulting in the emergence of the new urban form or 'multifunctional, multinuclear spatial structure'. Following Castells (but also Hall and PAIN, 2006), three main spatial levels are considered here: (1) Dublin's city centre/CBD, (2) the Dublin metropolitan area, and (3) the Greater Dublin region. For the purposes of this paper, the Greater Dublin region is defined as a functional urban region comprising the Dublin metropolitan area and four surrounding local authorities in its "hinterland' (County Louth, County Meath, County Kildare and County Wicklow). In turn, the Dublin metropolitan area is defined as comprising the following four 'metropolitan' local authorities: Dublin City, Fingal, Dublin South and Dun Loaghaire-Rathdown. Finally, Dublin's CBD is defined as comprising three postcode areas in the very centre of Dublin City - Dublin 1, Dublin 2 and Dublin 4. The focus of the present study is on decentralization within the Dublin metropolitan area (from city centre to suburbs) and within the Greater Dublin region (from Dublin to surrounding urban centres).

In order to examine decentralizing tendencies from Dublin to the surrounding hinterland, nine major urban centres outside Dublin City have been selected. While still relatively small, all these urban centres have experienced dramatic population growth in the last decade or so (Table 1). Of interest was to find out whether these centres (all within a 100-km radius of Dublin) are also becoming major locations for KIBS. 
Table 1. Selected urban centres outside Dublin

\begin{tabular}{|c|c|c|c|c|c|}
\hline \multirow[b]{2}{*}{ Urban centre } & \multicolumn{3}{|c|}{$\begin{array}{l}\text { Total population (includ- } \\
\text { ing suburbs or environs) }\end{array}$} & \multirow{2}{*}{$\begin{array}{c}\text { Population } \\
\text { change, } \\
1996-2006(\%)\end{array}$} & \multirow[b]{2}{*}{ Note } \\
\hline & 1996 & 2002 & 2006 & & \\
\hline Drogheda & 25282 & 31020 & 35090 & 38.8 & $\begin{array}{l}\text { Ireland's largest provincial town. Previously industrial and a port town, } \\
\text { becoming an established commuter town of Dublin }\end{array}$ \\
\hline Dundalk & 30195 & 32505 & 35085 & 16.2 & $\begin{array}{l}\text { Administrative centre of County Louth. Previously industrial and a port } \\
\text { town, now developing a niche expertise in digital media }\end{array}$ \\
\hline Bray & 27923 & 30951 & 31901 & 14.2 & Established suburb of Dublin with recent new economy developments \\
\hline $\begin{array}{l}\text { Navan } \\
\qquad \text { (An Uaimh) }\end{array}$ & 12810 & 19417 & 24851 & 94.0 & $\begin{array}{l}\text { Principal town and administrative centre of County Meath, becoming a } \\
\text { commuter town of Dublin }\end{array}$ \\
\hline Naas & 14074 & 18288 & 20044 & 42.4 & $\begin{array}{l}\text { Administrative centre of County Kildare. Market town; developing as a } \\
\text { commuter town }\end{array}$ \\
\hline $\begin{array}{l}\text { Newbridge } \\
\text { (Droichead Nua) }\end{array}$ & 13363 & 16739 & 18520 & 38.6 & Market and industrial town, now affected by commuting developments \\
\hline Balbriggan & 8473 & 10294 & 15559 & 83.6 & $\begin{array}{l}\text { Previously industrial and a market town, now experiencing high levels of } \\
\text { residential commuter development }\end{array}$ \\
\hline Maynooth & 8528 & 10151 & 10715 & 25.6 & University and market town, recently developing as a commuter centre \\
\hline Wicklow & 7290 & 9355 & 10070 & 38.1 & $\begin{array}{l}\text { Administrative centre of County Wicklow. A market town with recent } \\
\text { commuter developments }\end{array}$ \\
\hline
\end{tabular}

Source: Central Statistics Office (CSO) (2007); and authors' own work.

In line with the 'informational city' hypothesis, the main interest focuses on specialized KIBS. ${ }^{4}$ The following eight KIBS sectors have been considered: banking/finance, insurance, management consultancy, accountancy, law, advertising, logistics, and design consultancies. Some of them (e.g. international financial services within banking/finance/insurance) could be labelled as 'internationally traded services' (cf. Breathnach, 2000; Grimes, 2003; Grimes and White, 2005), while others are predominantly oriented to domestic markets (e.g. domestic banking, domestic insurance, law and accountancy firms, management consultancies, architecture firms, etc.) with either national or regional market scope. In some cases, however, market boundaries are much harder to establish (e.g. in logistics). There are also instances where domestic KIBS and foreign-oriented KIBS simply provide markets for each other.

To date, the above KIBS sectors have not been comprehensively studied in the Irish context. Certainly, the existing literature provides useful insights into the growth of internationally traded services in Ireland (Breathnach, 2000; Grimes, 2003; Grimes and White, 2005), some of which may be part of larger manufacturing or software-producing corporations. However, the present study represents the first attempt to examine service-specific KIBS firms while focusing on their locational pattern within the Greater Dublin region.

This is not an easy task given that there are no reliable statistics on the subject. The present authors' own attempt to provide a preliminary picture at the level of the Greater Dublin region is captured in Fig. 1. In line with Castells's hypothesis, it focuses on the spread of operations of multi-location KIBS firms. It is based on information collected from various sources, including sectoral organizations, regulatory bodies and corporate sources. Although Fig. 1 needs to be treated with caution, it nevertheless clearly shows that, in the case of the Greater Dublin region, there is very little evidence of decentralization of KIBS outside the metropolitan area (also VAN EgERAAT et al., 2006).

Indeed, in the urban centres around Dublin larger, multi-office KIBS are very rare. They can be found, however, in sectors such as accounting and design consulting (architecture or engineering), but these are typically operating within regional or national market scopes of service provision. The only other significant KIBS presence outside the Dublin metropolitan area consists of a network of operations of financial services (banking and insurance). Almost exclusively, however, these networks are made up of local (retail) branches. Perhaps more importantly, there is also a small number of decentralized back offices or call centres from major financial players (headquartered in Dublin). One way or another, the operations that have been decentralized are clearly subordinated to a higher level of decision-making invariably located in the capital city. The operations in question are, in other words, part of a highly hierarchical corporate structure and highly centralized functional/informational flows dominated by a single centre - Dublin thus compounding uneven regional geography. It is therefore hard to talk about a 'balanced' polycentricity, i.e. a balanced spread of KIBS functions across the region.

The potential for the increased presence of decentralized operations in Dublin's hinterland in the future should not be underestimated. However, at the present time, at the regional level at least (i.e. outside 


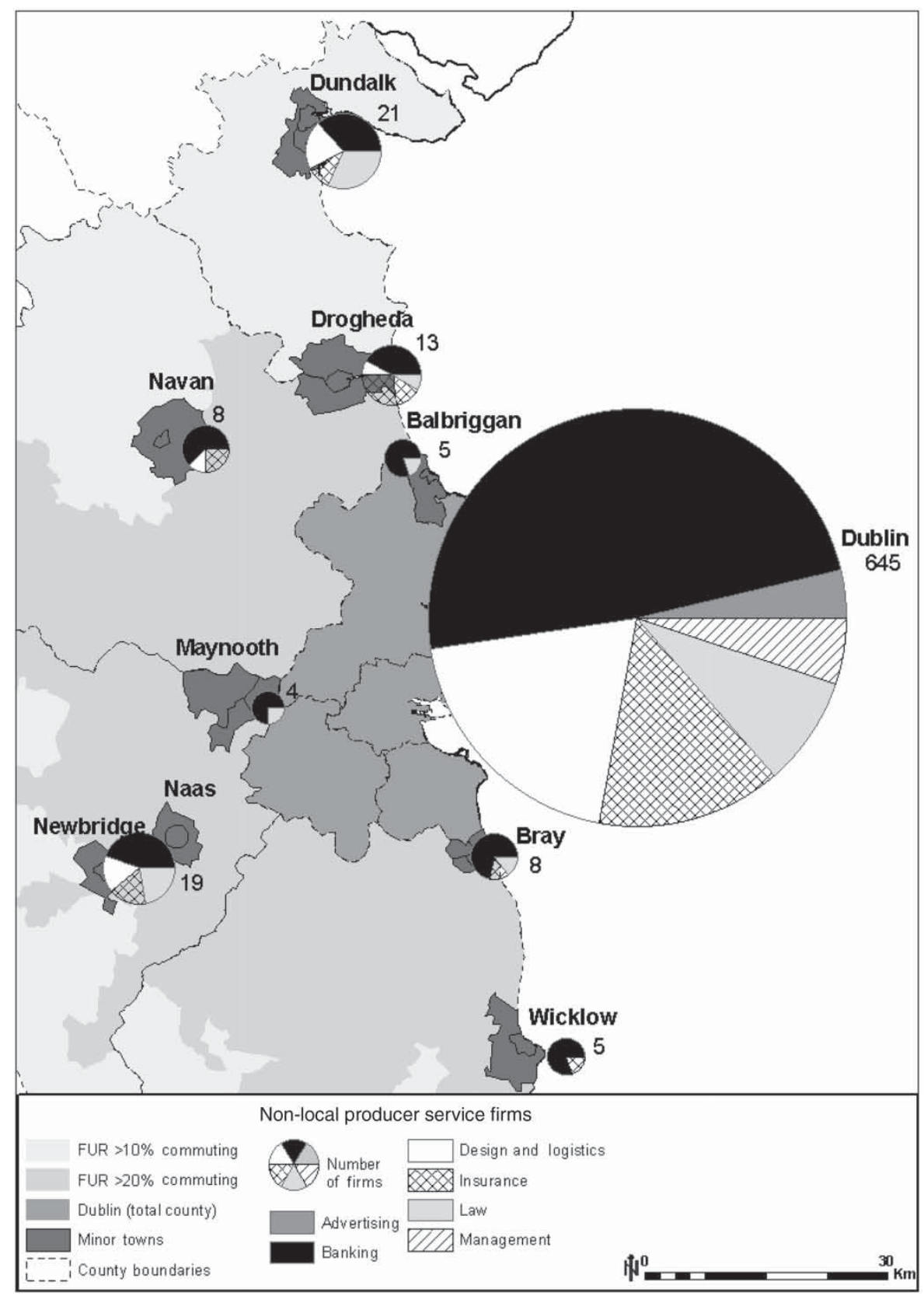

Fig. 1. Distribution of multi-location knowledge-intensive business services (KIBS) firms in the Greater Dublin region, Ireland Source: Adapted from VAN EgeraAt and SOKOL (2006, p. 160)

Dublin's metropolitan area), a 'multifunctional, multinuclear spatial structure' does not seem to be a dominant feature (also SOKOL and VAN EgERAat, 2005a, b).

The picture is more complex when processes within the metropolitan area of Dublin are considered. Here there is some evidence to suggest that a limited decentralization is taking place, in line with what CASTELLS (1989) calls 'suburbanization' of business activities and HALL and PAIN (2006, p. 11) identify as decentralization to 'edge city' locations. Indeed, in the last two decades or so, Dublin has experienced a major upsurge in the construction of office space in its suburbs (MACLARAN and O'Connell, 2001; Maclaran and Killen, 2002; Bertz, 2002). Some of these developments can be seen as contributing to the emergence of 'edge cities' in Dublin, especially around the M50 C-ring motorway (Williams and SHiels, 2000; MacLaran, 2004). The present authors found several examples of KIBS moving their entire operation or parts of their operations into such sites including those in Tallaght and Sandyford-Leopardstown. Other suburban office parks and office locations capable of accommodating KIBS include Blanchardstown, Palmerstown, Citywest and Parkwest, among others. However, relatively high vacancy rates in some of these office developments 
(Maclaran, 2004; Bertz and Foley, 2006) suggest that decentralization to suburban locations has clear limits. Indeed, the bulk of Irish KIBS remain stubbornly anchored in Dublin's CBD - an epicentre of metropolitan, regional and national KIBS activity. ${ }^{5}$ As for those operations that have been decentralized to suburbs, these rarely outstrip the volume and quality of functions of their parents in Dublin's city centre, again suggesting imbalances in corporate spatial structure. In addition, the current pattern of office suburbanization within metropolitan Dublin could be seen as 'highly inappropriate and inefficient' (MACLARAN and Killen, 2002 , p. 34), not least because it encourages the emergence of an unsustainable, car-dependant urban form. Therefore, the evolving forms within the metropolitan area of Dublin cannot be automatically equated with a balanced and sustainable polycentric development.

In conclusion, the above picture of KIBS geography does not seem to imply that either dramatically new 'spatial logic' or more balanced development is emerging in and around Dublin. To understand the reasons behind this, qualitative evidence was gathered via interviews allowing insights to be gained into the factors that underpin both the current and future locational patterns of KIBS. The aim of the interviews was (1) to help explain why decentralization of KIBS operations in and around Dublin has been rather limited so far, and (2) to ascertain whether there are any factors that may act as impulses for a larger-scale decentralization process in the near future.

More than 100 semi-structured interviews took place in the Greater Dublin region. Of this number, over 20 interviews were undertaken with institutional players, such as sectoral or local 'gatekeepers' including representatives of relevant local authorities, industry associations, professional bodies and sectoral experts. Nearly 90 interviews were conducted with senior business managers of multi-location KIBS in the eight aforementioned sectors. The sampling strategy for firm interviews aimed at achieving, wherever possible, a cross-section of firms by urban centre, market scope and sector (for more details, see SOKOL and VAN EgERAAT, 2005a, b).

A wealth of qualitative data have been produced through this interviewing effort. Despite this, the authors do not claim that these data are representative of the entire population of KIBS in the region. Generalizations are also difficult because of a huge diversity that exists between and within KIBS sectors. There is not enough space to elaborate on this point herein, although responses from managers of KIBS presented below provide a good illustration of this. However, what emerged clearly from the interviews is that, rather than resulting from some universal 'spatial logic' driven by ICT, the geography of KIBS is contingent on a host of complex factors. Focus is made here on three factors that appear to be dominant: (1) firms' own corporate strategies, (2) the conditions of the labour market, and (3) the role of the state. As will be demonstrated below, these three factors are highly interrelated and are strongly influencing each other, while interacting with a plethora of other overlapping factors.

\section{CORPORATE STRATEGIES AND THEIR SPATIAL IMPLICATIONS}

In line with Castells's arguments, it can be said that corporate strategies of KIBS play a pivotal role in understanding the geography of knowledge-intensive services. These strategies can also be seen as resulting from a series of tensions, one of which is a locational tension' (Hoyler and Pain, 2001). In the case of Dublin, it needs to be understood why this locational tension is predominantly resolved through locating in the city centre $(\mathrm{CBD})$ and whether there are factors or tensions that may encourage more decentralization in the future.

The interviews helped reasons behind the concentration of KIBS in Dublin metropolitan area to be identified. Respondents in all sectors strongly emphasized that Dublin represents both the most important market for their services and provides much of their labour. Many managers also highlighted the connectivity to transport infrastructure both nationally (roads, rail) and internationally (airport). A senior management consultant summed up the importance of Dublin as follows:

So the talent pool is here. The client base is here. The infrastructure is here, so that's why we are here.

(Interview, mc04-07, 2004)

As for the location decisions within the metropolitan area, the three issues of clients, labour and (transport) infrastructure again dominated, strongly favouring locations of KIBS in the centre of Dublin. On the client accessibility side, face-to-face contacts remain critical for most KIBS and proximity to, or accessibility to/by, clients is regarded as essential. Due to the predominantly radial transport pattern in Dublin, this is best achieved in the city centre. The same applies to accessibility by staff (see the fifth section).

There are further advantages that the CBD has to offer. Several respondents, for instance, pointed to the importance of proximity of related professional services. Senior managers in design and advertising firms perceived the area as displaying a 'cluster effect' (e.g. Interview, dc08-20, 2004). A number of respondents also praised the relative spatial compactness of the CBD, which allows them to walk to most of their business meetings. Other important factors contributing to the attractiveness of the city centre location include the need for a prestigious location, the office building as a form of investment asset, better opportunities for subletting (vacant) office space, proximity to amenities 
and the attractiveness of urban environment including opportunities for socializing.

In addition to the above factors that continue to play a key role in the 'traditional' clustering of service firms in Dublin 2 and Dublin 4 areas (BANNON, 1973), government policy has undeniably influenced the emergence of a major concentration of KIBS in the International Financial Service Centre (IFSC) in the former Docklands area in Dublin 1 (see the sixth section). Importantly, interviewed IFSC companies seem to be relatively happy to stay in the area, despite the fact that the importance of some of the original incentives has been recently weakening. For these companies, due to the nature of their operations, the reliability of telecommunication infrastructure is also a major concern. In fact, as one of the informed banking experts noted, it is evident that ICT infrastructure, connecting Dublin with the rest of the world, was critical to the development of international financial services in IFSC (Interview, ii02-00, 2004).

While the advantages (or 'economies') of locating in Dublin's city centre are considerable, managers of firms also identified factors that may promote centrifugal tendencies and eventual decentralization of certain KIBS away from the CBD. Among the disadvantages that managers associated with city-central location were classic 'diseconomies' factors such as traffic congestion and cost (and in some cases unsuitability) of office accommodation, and also the lack of parking spaces for staff and clients (restricted by local planning authorities). However, despite these constraints, the pull of the CBD remains strong at the moment.

The question is whether there are any factors that may change this current pattern in favour of decentralization in the future. However, very little evidence was found for this. Very few KIBS firms that were interviewed were actively considering relocating to suburban locations (e.g. around the M50), and it is not clear whether such a move will eventually materialize. Indeed, there is a concern among many managers that the expected benefits of relocation to suburbia (such as cheaper office accommodation) may not compensate for the lost advantages of a central location. While one or two firms indicated that a 'signature building' may attract them to a suburban site, others expressed concern that office parks in the edges of Dublin may become 'ghosts towns'. Keeping city-central location is therefore seen as the safest bet.

Even less impetus among KIBS managers is for decentralization to locations outside the metropolitan area. It was found that there are huge perceived risks of such a dramatic locational change. Indeed, when asked about the implications of a potential move to smaller urban centres around the capital city, most firms indicated that they would be risking losing either staff or clients, or both. In the case of an architectural practice, a move outside Dublin would be a matter of 'losing soul' too (Interview, dc03-25, 2004).
While the potential relocation of entire KIBS firms into suburbs or beyond is very limited, in some cases large players are decentralizing parts of their operations. The banking sector is perhaps the best example of this process. As explained by a Deputy chief executive officer (CEO) of a major bank, amid competitive pressures, location becomes 'an important dimension to cost management' (Interview, bk01-02, 2004). Consequently, some more routine, back-office operations are being relocated to Dublin's suburbs or further afield. The distance from Dublin may be an important element in locational decision-making where the intention of tapping into a particular labour market outside the reach of the capital city (see below) has to be balanced against the requirement of an easy managerial reach (a comfortable car drive from a Dublin head office). However, it would be too early to consider this process of backoffice decentralization as a beginning of a new multinucleated or polycentric city-region. In fact, sceptics could argue that there is no guarantee that this decentralization will automatically favour urban centres within the Greater Dublin Region. Indeed, some operations may simply be outsourced or decentralized to more remote parts of Ireland or even internationally, with Dublin's hinterland losing to cheaper locations in Eastern Europe or Asia, for instance.

Having said this, it is important to recognize that for large international financial services players, Dublin itself is a 'decentralized' location (Interview, bk14-00, 2004) within much larger corporate networks. In other words, Dublin can be at the receiving end of functions relocated from other (even higher cost) locations such as London. Exceptionally, large international players may even choose smaller urban centres outside Dublin metropolitan area as a location for their decentralized operations (as was the case of one insurance company). Such a move would benefit from advantages of escaping Dublin's expensive office accommodation while still tapping into the labour pool of the capital. This latter case also leads one to consider the operation of labour market and its impact on geography of KIBS.

\section{LABOUR MARKET AS A LOCATIONAL FACTOR}

It could be argued that skilled labour in general, and 'knowledge workers' in particular, are critical for the operation of KIBS. Consequently, labour market conditions also seem to play an important role (in fact, sometimes the key role) in determining locations of KIBS activities. As revealed by the interviews in the Greater Dublin region, labour markets also have a significant 'inertia' effect on the 'movement' of offices. Once established, it is often considered problematic (if not impossible) to relocate an office to a new location, largely because of the reluctance of its staff to move. As a manager of a Dublin-based logistics company 
plainly put it, 'people would not move' (Interview, $\log 00-08,2004)$. The interviewee added 'we could not just move this office out of here to Naas and 95 percent of our staff living in Dublin' (Interview, $\log 00-08,2004)$. A business person in the insurance sector contemplated a hypothetical move from Dublin to Drogheda (some $50 \mathrm{~km}$ north of Dublin) in the following way:

How could you operate in Drogheda? Half your management team would leave; all the sales people would look for a new job in Dublin....

(Interview, in00-07, 2004)

Interestingly, for a regionally based, out-of-Dublin design practice, moving to a new location is not an option either. As the manager of the firm maintains, this would result in losing half of its staff and therefore would represent a 'suicide in this business' (Interview, dc04-27, 2004). What the above statements point at is that the labour market in the Greater Dublin Region is characterized by a significant 'spatial rigidity'. This 'rigidity' applies to moves both between urban centres in the region and within the Dublin metropolitan area. Indeed, within Dublin itself, several managers indicated that a move to a different location (from the city centre to the suburbs, or from one part of the metropolitan area to another) could be problematic. Many employers thus prefer central location because:

Funnily enough a city centre location is seen as the fairest for staff. If we were to move, we are going to disenfranchise some group of staff.

(Interview, in00-07, 2004)

On the other hand, in certain circumstances firms may see a disruption of their existing labour force as 'desirable'. This is especially true when firms are seeking efficiency gains via reduced labour costs and/or an introduction of new labour practices. In such cases, KIBS firms are using the strategy (similar to their manufacturing counterparts) of relocating operations precisely in order to instigate a labour changeover. There is some evidence to suggest that this is indeed happening. Indeed, several financial services providers indicated during the interviews that their decision to open new back-office facilities outside the capital city was partly influenced by the desire to move away from the overheated labour market in Dublin. Such firms target more remote locations (often beyond the boundaries of the Greater Dublin Region) and more remote labour markets where they can recruit staff who are perceived as generally cheaper, more loyal and more flexible.

Another interesting (if hardly surprising) aspect of the survey results on labour market in and around the capital city is a residential geographical 'segmentation'. Many people are simply priced out of the Dublin housing market and end up commuting from various locations within the sprawling metropolis and beyond (also Williams and Shiels, 2000, 2002a). Having said that, there are people who actually do prefer to live (and work) in smaller towns or more rural settings. The issue is that such locations may not be able to offer jobs that would suit their qualifications and career aspirations. This leads to a consideration of the differences between Dublin and surrounding urban centres in terms of labour supply and demand.

It is safe to argue that Dublin metropolis dominates the entire city-region in both labour supply and demand. For KIBS firms, Dublin is seen as a large pool of talent into which they can tap. In fact, some skills are only available in the capital city (thus clearly constraining locational choices of KIBS firms). For instance, a CEO of an advertising firm suggested the following:

If we were up in Dundalk, we wouldn't be able to recruit the people [...] Students who want to get into advertising wouldn't go there [...] You just would not get people who want to work in advertising [...] if we move down to Cork, or even 50 miles out of Dublin, you would have no staff. It would be impossible to find the skills in a town like Naas.

(Interview, ad00-08, 2004)

Importantly, Dublin provides a continuous stream of graduates from its universities where KIBS providers recruit from every year. The attractiveness of Dublin is also important and works as a 'magnet', especially for younger people, who 'like to live in Dublin [...] Dublin has an attraction socially which I don't think you would get in Naas or Navan' (Interview, lw0005, 2004). It could be added that a prestige and image of a particular place also plays a role for both firms and people.

One way or another, the smaller towns in the study area have a relatively limited supply of professional staff. It is possible that one faces a circular and cumulative causation (MYRDAL, 1957) or a 'chicken-and-egg' problem here. Large KIBS firms would not move to these centres because there is not enough relevant staff, and vice versa. By the same token, jobs in KIBS sectors attract skilled professionals, but also skilled labour attracts KIBS firms. It could be argued that this is just a part of a wider circular and cumulative causation in the "knowledge economy', reinforcing existing (uneven) urbanregional patterns and thus working against balanced regional development (cf. SOKOL and TOMANEY, 2001). Such a process would also work against a polycentric development and will be hard to reverse without a policy intervention (cf. BANNON, 2004) to which the present paper now turns.

\section{PUBLIC POLICY AND THE ROLE OF STATE}

The Irish case demonstrates that public policy can make a difference and that, more generally, the role of the state at various scales still does matter. Indeed, various levels of governance, from local to regional to national to 
supra-national, individually or in combination, exercise considerable influence over economic affairs. A good example of this is an aforementioned concentration of financial services into Dublin's IFSC, created through national government intervention and European Union tax concessions, and connecting the city with global 'space of flows' (for more details, see MURPHY, 1998; Williams and Shiels, 2002b; White, 2005; and SOKOL, 2007).

However, while the economic success of Dublin is welcome, it also fuels space-economic imbalances at national, regional and metropolitan levels (SOKOL, 2005). Therefore, the key question for the present study is whether the state and public policies are encouraging the emergence of a polycentric cityregion and balanced development in and around Dublin. This research suggests a mixed picture, as policy-makers are facing major dilemmas.

These dilemmas are perhaps most apparent at the level of national policy-making. The difficulty is that national policy finds itself in a continuous tension between the need to foster competitiveness and, simultaneously, to promote balanced development. This tension has been reflected in the National Development Plan (Government of IreLAND, 2000), generously part-financed by European Union funding. The plan, on the one hand, seeks to address bottlenecks in Dublin (seen as the engine of the Irish economy) and, on the other hand, aims to support balanced regional development for the rest of the country.

There are no easy solutions to the above conundrum, however. Interviews with experts working in the field of inward investment confirmed that, in the case of international financial services for instance, investors are encouraged to set up front office/head office-type operations in the capital city, while the rest of the country is promoted as being more suitable for back office functions (Interview, ii01-00, 2004; Interview, ii02-00, 2004). Occasionally, urban centres in Dublin's hinterland may benefit from such a promotional effort, but it remains to be seen if such an approach will bring about balanced development within the Greater Dublin region.

In the meantime, an intervention at the regional level may be considered as suitable. However, regional governance in Ireland is rather weak (MORGENROTH, 2000). While the strategic regional documents (e.g. Regional Planning Guidelines) are officially promoting a polycentric city-region around Dublin, strong implementation mechanisms are missing (for more, see SOKOL and VAN EgERAAT, 2005b; STAFFORD et al., 2005; CONVERY et al., 2006; and SOKOL et al., 2006).

In comparison, the local state (city and county councils) has currently more leeway for influencing corporate behaviour and the location of KIBS, or businesses more generally. Interviews with senior planning and economic development officers of local authorities outside the Dublin metropolitan area (Counties Louth, Meath, Kildare and Wicklow) indicated a strong desire to capitalize further on advantages their areas offer to potential investors. The advantages (as compared with Dublin) most frequently quoted by the interviewees included better quality of life, cheaper housing, cheaper office space, and the availability of a labour force eager to abandon the commute to Dublin in favour of working locally, even at lower wages. Recently, three local authorities of the Mid-East region (Kildare, Meath and Wicklow) have considered policies of encouraging Dublin-based businesses to relocate in the hinterland (e.g. Interview, ii18-00, 2004; Interview, ii20-00, 2004) in an attempt to boost their income from local business rates. It remains to be seen what effect such initiatives will have on their economic fortunes or their share of KIBS.

In the meantime, economic strategists at the local (county) level start to realize that they cannot compete on a cost basis alone and are keen to develop more knowledge-intensive and value-added business. Thus, strategies are being developed in County Louth to promote, for instance, a multimedia cluster in Dundalk (Interview, ii17-06, 2004) as part of the effort to foster 'knowledge based industry' (Interview, ii17-04, 2004). Similar thoughts are emerging in County Kildare, which is working on its own development strategy amid the growing realization that the rules of the game for attracting investment are changing with the advent of the globalizing economy (Interview, ii19-12, 2004).

It is important to recognize, however, that local authorities within the Dublin metropolitan area do not remain passive. They are active players in the competition for investment and economic success. For instance, the Dublin City Development Board, the economic development arm of the Dublin City Council, works actively to foster a favourable business environment in the city. This includes strengthening telecommunications infrastructure and harnessing ICT to support the transition 'from an investment driven society to a knowledge driven society' (Interview, ii13-01, 2004). Therefore, it seems that in the case of Dublin city the combined forces of the state (local and national) work together to accommodate rather than reverse the centralizing tendencies of KIBS. On the other hand, it could be argued that the initiatives of the counties in Dublin's hinterland may provide some impulses for decentralization of certain KIBS operations. However, it is not clear if such decentralization will provide a balance to overwhelmingly centripetal tendencies of KIBS and in doing so instigate a 'new spatial logic' as portrayed by CASTELLS (1989). This leads to a reconsideration of the 'informational city'.

\section{BEYOND THE 'INFORMATIONAL CITY'}

In the light of the evidence presented above, Castells's thesis looks problematic, but a theory cannot be rejected 
on the basis of a single case study. Instead, the authors would like to undertake a careful interpretation of their findings and, where appropriate, to advance the argument further.

The key consideration has to be given to the factors that impinge upon the processes of centralization and decentralization. As shown in the present study, these two processes are not universally present on the economic landscape. Instead, it could be argued that these processes work differently at different spatial scales. In the present case, decentralization is very limited at the regional level, while at the metropolitan level, a twofold process of simultaneous spatial centralization and decentralization is more evident. At both spatial scales, centralization seems to be dominant, however. The question arises as to why, in the case of Dublin, centralization and decentralization processes are not in balance.

Several hypotheses can be put forward. One obvious proposition would be to highlight the role of size. It could be imagined that Dublin is simply too small a metropolis to display processes expected from a major 'informational city' by Castells. Indeed, it is plausible that the (limited) size of Dublin has an impact both on the size/type of KIBS operations and on their locational distribution. This would imply that metropolitan areas considered by Castells are not displaying universal patterns, but instead are behaving differently according to their size. However, the case of a rather monocentric Paris region (HALBERT, 2008), which is ten times bigger than Dublin, underlines the fact that the level of polycentricity is not necessarily a function of size either (also Hall and Pain, 2006).

Another hypothesis is that the 'new spatial logic' has not yet fully materialized and has yet to supersede the old spatial form. This would imply that the pre-existing urban pattern of the Greater Dublin region, characterized by a strong dominance of Dublin, is likely to continue for some time. In other words, the process of a circular and cumulative causation will continue until old historical legacies associated with this urban pattern (e.g. transport infrastructure centred on Dublin) will be subverted by a new logic driven by ICT. It is also possible that the 'new spatial form' will never materialize, in Dublin or elsewhere, if Castells and other thinkers overestimated the decentralizing power of ICT.

Yet another possibility is that the processes of centralization and decentralization do work as predicted by Castells, but are operating at much higher spatial scales. If so, one would need to zoom out of relatively small metropolitan and regional scales and consider Dublin as operating within 'space of flows' at international and global scales. Seen from this perspective, Dublin could be considered, in Castells's language (CASTELLS, 2000, p. 440), as a 'hub' at a receiving end of decentralized KIBS operations from global 'nodal points' or 'mega-cities' such as London or
New York. One way or another these tentative hypotheses could have important implications for the way the 'new spatial logic' is understood or conceptualized.

A further point to note relates to the alleged drivers of the 'new spatial logic': KIBS themselves. Despite some common features, a huge diversity was found among KIBS firms in the way they organize and locate their operations. There are big differences both between and within KIBS sectors. For instance, creative or teamwork-based firms (e.g. in advertising and management consultancy) usually have only a single office within the region, invariably located in Dublin. Meanwhile, financial services firms display perhaps the biggest propensity to locate some of their operations outside the capital city, reflecting their complex internal division of labour. However, there are also significant differences with the financial services sector itself (for more details, see SокоL, 2007). One way or another some KIBS firms may have a bigger potential to fuel decentralization, while other firms display a fundamental lack of it. The bottom line is that there is no universal organizationalspatial logic of 'large-scale organizations' that would automatically contribute to the emergence of a 'multifunctional, multinuclear spatial structure'.

Despite all this diversity, it needs to be recognized that there is one logic shared by all KIBS - a business logic of profit-making. Indeed, it could be argued that the profit imperative has not been disrupted by the arrival of the 'knowledge-based economy' (SOKOL, 2004). KIBS are no exception to this rule and so while the flow of information may be critical to their operation, it is the creation and appropriation of surplus value that preoccupies their managers. Therefore, instead of 'space of flows' (read 'flow of information'), it is the 'flow of value' that is critical for the economic fortunes of firms, organizations, people and places. Indeed, the examination of geographies of economies may be more fruitfully approached through the prism of 'value chains' or 'value networks' (SMITH et al., 2002).

While all the above points suggest that the 'informational city' thesis needs further elaboration and testing, there is one concern that the authors do share with CAstells (1989) - the concern about the inequality produced under the 'new spatial logic'. Indeed, the evidence collected in the case of Dublin confirms that even where (modest) processes towards a 'multifunctional, multinuclear spatial structure' are in operation, the emerging spatial structure is highly uneven in its nature. Decentralized operations are usually subordinated to a higher level of decision-making invariably located in Dublin. In other words, such decentralized operations form part of a highly hierarchical corporate structure and sharp intra-firm spatial division of labour. This opens up the question about the implications of the 'new spatial logic' for balanced development, echoing old concerns about the uneven spatial divisions of labour (MASSEY, 1995). 
As discussed above, CAstells (1989) is aware of the 'hierarchical structure' and 'directionality' of the 'space of flows' and negative implications it can bring to people and places. Castells's strategy to counter the ever increasing power of 'space of flows' over the 'space of places' is through the 'renaissance of the local state' (p. 352) and 'a network of local communes controlling and shaping a network of productive flows' (p. 353). But as has been shown in the case of Dublin, local authorities are often mediating and welcoming the 'space of flows' rather than resisting it. In doing so, they often compete against each other, rather than forming cooperative networks. It is hard to see how local governments alone can master the 'space of flows'. Rather, it could be suggested that synchronized interventions at all governance levels need to be in operation if the hope of a more balanced development in the 'knowledge economy' is to last.

Acknowledgements - The authors are grateful to five anonymous referees for their comments. Also thanks to Daniel McInerney and Seán Morrish (Urban Institute Ireland) for providing cartographic assistance with Fig. 1. Special thanks to John Yarwood, Frank Convery, and Jon Healy for their support. This study was undertaken within the POLYNET project co-financed by the European Union Interreg IIIB programme. The usual disclaimers apply.

\section{NOTES}

1. Two additional dimensions of decentralization are represented by the offshoring of service activities abroad and the decentralization of office work at home ("telecommuting'; CASTELLS, 1989, p. 152).

2. For an interesting discussion on forces for agglomeration and de-agglomeration, see also LEAMER and STORPER (2001), who also acknowledge that the geography of the Internet Age will be dominated by increasingly large and internally polycentric' metropolitan areas (p. 658).

3. These communication flows, however, are notoriously hard to measure (HALL and PAIN, 2006).

4. The prominence of KIBS is also emphasized by HALL and PAIN (2006) and GaWC researchers (e.g. TAYLOR et al., 2002). See also the work of LEAMER and STORPER (2001, p. 642) who emphasize the importance of 'specialized firms' producing 'intellectual inputs' for other businesses.

5. Perhaps with the exception of logistics firms that seem to favour locations close to Dublin airport.

\section{REFERENCES}

BAILEy N. and TUROK I. (2001) Central Scotland as a polycentric urban region: useful planning concept or chimera, Urban Studies 38, 697-715.

BAnNon M. J. (1973) Office Location in Ireland: The Role of Central Dublin. An Foras Forbartha, Dublin.

BANNON M. J. (2004) Service activity concentration in Dublin and its implications for national urban policy and the regional development of the country. Paper presented at the Urban Institute Ireland/CREG Guest Lecture Series, University College Dublin (UCD), Dublin, Ireland, 3 June 2004.

Bertz S. (2002) The peripheralisation of office development in the Dublin metropolitan area - the interrelationship between planning and development interests, Irish Geography 32, 197-212.

Bertz S. and Foley R. (2006) Understanding commuting patterns to business parks in Dublin. Paper presented at the Annual Conference of Irish Geographers, University College Dublin (UCD), Dublin, Ireland, 5-7 May 2006.

BREATHNACH P. (2000) Globalisation, information technology and the emergence of niche transnational cities: the growth of the call centre sector in Dublin, Geoforum 31, 477-485.

CAstells M. (1989) The Informational City: Information Technology, Economic Restructuring and the Urban-Regional Process. Blackwell, Oxford.

Castells M. (2000) The Information Age: Economy, Society and Culture, Vol. I: The Rise of the Network Society, 2nd Edn. Blackwell, Oxford.

Castells M. (2001) The Internet Galaxy: Reflections of the Internet, Business, and Society. Oxford University Press, Oxford.

CASTELlS M. (2004) Informationalism, networks, and the network society: a theoretical blueprint, in CASTeLLS M. (Ed.) The Network Society: A Cross-Cultural Perspective, pp. 3-45. Edward Elgar, Cheltenham.

Central Statistics Office (CSO) (2007) Census 2006: Principal Demographic Results. The Stationery Office/Government of Ireland, Dublin. (available at: http://www.cso.ie/census/Census2006_Principal_Demographic_Results.htm) (accessed on 20 June 2007).

Convery F., McInerney D., Sokol M. and Stafford P. (2006) Organising space in a dynamic economy - insights for policy from the Irish experience, Built Environment 32, 172-182.

DAvOUDI S. (2003) Polycentricity in European spatial planning: from an analytical tool to a normative agenda, European Planning Studies 11, 979-999.

European Communities (1999) ESDP European Spatial Development Perspective: Towards Balanced and Sustainable Development of the Territory of the European Union. Office for Official Publications of the European Communities, Luxembourg.

Government Of Ireland (2000) Ireland: National Development Plan 2000-2006. The Stationery Office, Dublin.

GRIMES S. (2003) Ireland's emerging information economy: recent trends and future prospects, Regional Studies 37, 3-14.

GRImes S. and White M. (2005) The transition to internationally traded services in Ireland's emergence as a 'successful' European region, Environment and Planning A 37, 2169-2188. 
Halbert L. (2008) Examining the mega-city-region hypothesis: evidence from the Paris City-Region/Bassin parisien, Regional Studies, DOI: 10.1080/00343400701861328.

Hall P. (1999) Planning for the mega-city: a new Eastern Asian urban form?, in Brotchie J., Newton P., Hall P. and Dickey J. (Eds) East-West Perspectives on 21st Century Urban Development: Sustainable Eastern and Western Cities in the New Millennium, pp. 3-36. Ashgate, Aldershot.

Hall P. and Pain K. (Eds) (2006) The Polycentric Metropolis: Learning from Mega-City Regions in Europe. Earthscan, London.

Hoyler M. and Pain K. (2001) London and Frankfurt as World Cities: Changing Local-Global Relations. GaWC Research Bulletin No. 62 (available at: http://www.lboro.ac.uk/gawc/rb/rb62.html).

JENSEN O. B. and RichARDSON T. (2001) Nested visions: new rationalities of space in European spatial planning, Regional Studies 35, 703-717.

Kloosterman R. C. and Lambregts B. (2001) Clustering of economic activities in polycentric urban regions: the case of the Randstad, Urban Studies 38, 717-732.

Kloosterman R. C. and Musterd S. (2001) The polycentric urban region: towards a research agenda, Urban Studies 38, $623-633$.

Leamer E. and Storper M. (2001) The economic geography of the internet age, Journal of International Business Studies 32, 641-666.

MacLARAN A. (2004) Negotiating urban space: from frying pan of congestion to fire of suburbanisation. Whiter planning? Paper presented at the Urban Institute Ireland/CREG Guest Lecture Series (City-Regions: Economic Change, Technology and Knowledge Society Research Group), University College Dublin, Dublin, Ireland, 29 April, 2004.

MacLARAN A. and KilLen J. (2002) The suburbanisation of office development in Dublin and its transport implications, Journal of Irish Urban Studies 1, 21-35.

Maclaran A. and O'Connell R. (2001) The changing geography of office development in Dublin, in Drudy P. J. and MacLaran A. (Eds) Dublin: Economic and Social Trends, Vol. 3, pp. 25-37. The Centre for Urban and Regional Studies, Trinity College Dublin, Dublin.

MASSEy D. (1995) Spatial Divisions of Labour: Social Structures and the Geography of Production, 2nd Edn. Macmillan, London.

Morgenroth E. (2000) Regionalisation and the functions of regional and local government, in BARRetT A. (Ed.) Budget Perspectives. Proceedings of a Conference held on 19 September 2000 (available at: http://www.esri.ie) (accessed on 28 February 2005).

Murphy L. (1998) Financial engine or glorified back office? Dublin's International Financial Services Centre going global, Area 30, 157-165.

Myrdal G. (1957) Economic Theory and Under-Developed Regions. Gerald Duckworth, London.

PARR J. B. (2004) The polycentric urban region: a closer inspection, Regional Studies 38, 231-240.

Richardson T. and Jensen O. B. (2000) Discourses of mobility and polycentric development: a contested view of European spatial planning, European Planning Studies 8, 503-520.

SASSEn S. (2001) Global cities and global city-regions: a comparison, in ScotT A. J. (Ed.) Global City-Regions: Trends, Theory, Policy, pp. 78-95. Oxford University Press, Oxford.

Scott A. J., Agnew J., Soja E. W. and Storper M. (2001) Global city-regions, in Scott A. J. (Ed.) Global City-Regions: Trends, Theory, Policy, pp. 11-30. Oxford University Press, Oxford.

Smith A., Rainnie A., Dunford M., Hardy J., Hudson R. and Sadler D. (2002) Networks of value, commodities and regions: reworking divisions of labour in macro-regional economies, Progress in Human Geography 26, 41-63.

Sokol M. (2004) The 'knowledge economy': a critical view, in Cooke P. and Piccaluga A. (Eds) Regional Economies as Knowledge Laboratories, pp. 216-231. Edward Elgar, Cheltenham.

Sokol M. (2005) Dublin: Une region metropolitaine monocentrique? Paper presented at the Institut d'amenagment et d'Urbanisme de la Region d'Ile-de-France (IAURIF), Paris, France, 21 June 2005.

Sokol M. (2007) Space of flows, uneven regional development and the geography of financial services in Ireland, Growth and Change 38, 224-259.

Sokol M., Convery F. and Stafford P. (2006) Polycentric development and strategic spatial planning in Ireland. Paper presented at the Annual Conference of Irish Geographers, University College Dublin (UCD), Dublin, Ireland, 5-7 May 2006.

Sokol M. and Van Egeraat C. (2005a) POLYNET Action 2.1: Qualitative Analysis of Service Business Connections: Greater Dublin. Institute of Community Studies/The Young Foundation \& Polynet Partners, London (available at: http://www.polynet.org.uk/).

Sokol M. and VAn EgeraAt C. (2005b) Locational strategies of advanced producer services in Dublin: towards a polycentric mega-city region? Paper presented at the Regional Studies Association (RSA) Annual International Conference, 'Regional Growth Agendas' (Gateway 4: Strategic Spatial Planning), University of Aalborg, Aalborg, Denmark, 28-31 May (available at: http://www.regional-studies-assoc.ac.uk/events/280505papers.asp).

Sokol M. and Tomaney J. (2001) Regionalising the knowledge economy: what's the point?, in MACONOCHIE A. and HARDY S. (Eds) Regionalising the Knowledge Economy. Conference Proceedings of the Regional Studies Association Annual Conference, pp. 108-110. Regional Studies Association, Seaford.

Stafford P., Sokol M. and Convery F. (2005) The Greater Dublin Region: Analysis of Policy Responses, Identification of Key Policy Recommendations for Policy. POLYNET Report Action 3. University College Dublin, Urban Institute Ireland, Dublin (available at: http://www.polynet.org.uk/).

Taylor P. J., Walker D. R. F. and Beaverstock J. V. (2002) Firms and their global service networks, in Sassen S. (Ed.) Global Networks, Linked Cities, pp. 93-115. Routledge, New York, NY. 
Turok I. and BAiley N. (2004) The theory of polynuclear urban regions and its application to Central Scotland, European Planning Studies 12, 371-389.

Van Egeraat C. and Sokol M. (2005) Polycentricity in the Dublin Mega-City-Region: A Quantitative Analysis of Service Firm Connections. Working Paper Series No. UII 05/01. Urban Institute Ireland (UII), University College Dublin, Dublin.

Van Egeraat C. and Sokol M. (2006) Service firm connections in the Dublin-Belfast Corridor, in Yarwood J. (Ed.) The Dublin-Belfast Corridor: Ireland's Mega-City Region?, pp. 141-162. Ashgate, Aldershot.

Van Egeraat C., Sokol M. and Stafford P. (2006) Greater Dublin in the Celtic Tiger economy: towards a polycentric megacity region?, in Hall P. and PaIn K. (Eds) The Polycentric Metropolis: Learning from Mega-City Regions in Europe, pp. 187-194. Earthscan, London.

White M. (2005) Assessing the role of the International Financial Services Centre in Irish regional development, European Planning Studies 13, 387-405.

Williams B. and Shiels P. (2000) Acceleration into sprawl: causes and potential policy responses, Quarterly Economic Commentary (Economic and Social Research Institute, Dublin) June 37-73.

Williams B. and Shiels P. (2002a) The expansion of Dublin and the policy implications of dispersal, Journal of Irish Urban Studies $1,1-20$.

Williams B. and Shiels P. (2002b) The Financial Services Sector in Dublin. Cahiers de l'IAURIF No. 135, pp. 161-164. Institute of Urban Planning and Development, Paris. 